\title{
Prevalence of Antibodies to HIV among Students of Selected Tertiary Schools in Two Southwest States, Nigeria
}

\author{
Gabriel Olugbenga Daramola1 ${ }^{*}$, Adekemi Olubukunola Oluyege ${ }^{2}$, Helen Abike Edogun1, \\ Amos Olakunle Ojerinde ${ }^{3}$, Babatunde Ajayi Olofinbiyi ${ }^{4}$, Ayodele Oluwaseun Ajayi ${ }^{5}$, \\ Olugbenga Omoniyi Ajala6, Ogunbola Ogunfolakan7, Adebimpe Egbebi ${ }^{7}$, \\ Clement Olawale Esan ${ }^{8}$, Adegboyega Oladele Agbaje ${ }^{6}$
}

\author{
${ }^{1}$ Ekiti State University Teaching Hospital, Department of Medical, Microbiology and Parasitology, Ado-Ekiti, Nigeria \\ ${ }^{2}$ Ekiti State University, Department of Microbiology, Ado-Ekiti, Nigeria \\ ${ }^{3}$ Federal University, University Health Centre, Oye-Ekiti, Nigeria \\ ${ }^{4}$ Ekiti State University, Department of Obstetrics and Gynaecology, Ado-Ekiti, Nigeria \\ ${ }^{5}$ Federal University, Department of Microbiology, Oye-Ekiti, Nigeria \\ ${ }^{6}$ Ekiti State University Teaching Hospital, Department of Haematology and Blood Transfusion, Ado-Ekiti, Nigeria \\ ${ }^{7}$ AfeBabalola University, Department of Medical Laboratory Science, Ado-Ekiti, Nigeria \\ ${ }^{8}$ Ekiti State University, University Health Centre, Ado-Ekiti, Nigeria \\ Email: *gabrielodaramola@yahoo.com
}

How to cite this paper: Daramola, G.O., Oluyege, A.O., Edogun, H.A., Ojerinde, A.O., Olofinbiyi, B.A., Ajayi, A.O., Ajala, O.O., Ogunfolakan, O., Egbebi, A., Esan, C.O. and Agbaje, A.O. (2017) Prevalence of Antibodies to HIV among Students of Select Tertiary Schools in Two Southwest States, Nigeria. Journal of Biosciences and Medicines, 5, 83-96.

https://doi.org/10.4236/jbm.2017.58007

Received: June 15, 2017

Accepted: August 14, 2017

Published: August 17, 2017

Copyright $\odot 2017$ by authors and Scientific Research Publishing Inc. This work is licensed under the Creative Commons Attribution International License (CC BY 4.0).

http://creativecommons.org/licenses/by/4.0/ (c) (i) Open Access

\begin{abstract}
Young adults generally have been identified as one of the groups of individuals who are particularly at risk of contracting HIV/AIDS and undergraduates constitute a very significant subset among these young adults. Therefore this research was designed to study the specific factors that put undergraduates in ten selected tertiary institutions in southwest Nigeria at risk of contracting HIVAIDS, as well as determine HIV prevalence in these campuses and the viral load of positive subjects. 1000 undergraduates were enrolled in the study, over a period of forty-two months. Baseline retroviral screening was carried out, using a rapid commercial test-kit, DETERMINE ${ }^{\circledR}$. Confirmatory tests were carried out on positive samples using Enzyme Immuno Assay (EIA) technique. The viral load of the positive samples was determined using Real Time PCR, while the CD4+ count was assayed using Cyflow technique. Four out of the 1000 subjects were confirmed to be positive, thus representing an overall prevalence rate of $0.4 \%$. The CD4 count of the positive subjects were 479/L, 368/L, 420/L and 1063/L. Molecular analysis of the positive subjects' samples using RT-PCR revealed that the level of viral RNA in two of the subjects' was too low for detection, while the other two positive subjects had 20 $\mathrm{cp} / \mathrm{ml}$ and $325 \mathrm{cp} / \mathrm{ml}$ of viral RNA in their samples. Analyses of both the nega-
\end{abstract}


tive and positive subjects' questionnaires were carried out, so as to determine the probable risk-factors that predisposed the positive subjects to infection. Hypotheses tested at $\mathrm{p}<0.05$ revealed that there was a significant difference in the rate at which the subjects were infected with HIV among the age-groups.

\section{Keywords}

Seroprevalence, HIV, AIDS, Tertiary Schools, Undergraduates, Ekiti, Ondo

\section{Introduction}

It's been more than three decades ago since the first cases of HIV/AIDS were discovered in the US [1] and also almost three decades now since the first AIDS patient was discovered in Lagos, Nigeria [2]. Ever since these discoveries in the US and Nigeria, the disease has spread to virtually all the nooks and crannies of the globe, due mainly to international travels between one country and the other. Meanwhile, AIDS ravages the world, wrecking untold havocs in worst-hit nations of the world like the Southern Africa countries where in some places 1 out of every 4 working adults is infected. In such places, when the number of affected persons is factored into the HIV/AIDS disastrous equation, the percentage toll HIV/AIDS could be as high as half the entire country's population. This is because in such worst-hit nations, the large armies of the affected include among others, children orphaned by AIDS, those who died of AIDS, those whose personal economies can never be the same again as a result of the realities of HIV in their lives, aside the countless man-hours lost to HIV/AIDS-related clinic consultations [3] [4] [5]. One of the proactive measures that need to be taken in the battle against HIV/AIDS is the continual and continuous monitoring of seroprevalence levels among high-risk groups. And quite a lot of high-risk groups have identified, varying slightly from one country to another. In a country like Nigeria, some of the identified high-risk groups include long-distance commercial drivers, commercial sex-workers, injection-drug users and the youths. Youths who are undergraduates in the nation's universities and other higher institutions are particularly vulnerable to HIV infection for some reasons.

First, quite a lot of the youth-undergraduates engage in high-risk behaviours, like unprotected and indiscriminate sex, multiple sex-partners, skin-tattooing, needle-sharing practices and blood-based cult practices. Two, since most of them stay on campus, very far away from their parents, many of them who do not know how to manage freedom, see and use the distance between them and their parents as a license for all sorts of reckless and irresponsible activities. These among other reasons are why it'll always be necessary to keep an eye on the seroprevalence level of HIV among Nigerian undergraduates.

This study which is borne out of the above-stated need, investigated some of these high-risk reckless behaviours among undergraduates of ten selected tertiary institutions in Ekiti and Ondo States, aside prevalence and associated studies 
carried out amidst them.

\section{Materials and Method}

\subsection{Study Population}

A total of one thousand subjects were consecutively sampled from ten different tertiary institutions in the south-western states of Ekiti and Ondo, Nigeria. One hundred subjects each were consecutively sampled from the ten institutions of higher learning as depicted in Figure 1. There were no significant differences in the socio-demographic characteristics of the ten schools.

\subsection{School Ownership Structure}

Three of the schools were federal institutions ( 2 universities, 1 polytechnic); four were state-owned institutions ( 2 universities, 1 college of education and 1 college of health technology); 3 were private institutions ( 1 university, 1 polytechnic and 1 college of health technology).

\subsection{Study Period}

Collection of subjects' blood samples, administration of questionnaires and laboratory investigations of the subjects' blood samples were carried out over a period of forty months, that is between April, 2011 and July, 2014. The molecular studies of positive samples were carried out in September, 2014.

\subsection{Inclusion/Exclusion Criteria}

The inclusion criteria were; being a full/partial-time undergraduate student of one of the ten selected tertiary schools and willingness to volunteer a blood sample and fill the study questionnaire.

\subsection{Sample Collection and Preparation}

$4 \mathrm{ml}$ of whole blood samples were obtained from the participating undergraduates using venepuncture method. These were collected into Ethylene Diamine Tetra-acetic Acid (EDTA) at $1.5 \mathrm{mg} / \mathrm{mL}$ concentration. Samples were allowed to separate into plasma and corpuscles on the bench.

\subsection{Administration of Questionnaire}

The subjects were allowed to freely administer the study questionnaire on themselves without any external interferences or influences.

\subsection{Sample Testing}

\section{Baseline Testing}

Serial algorithm was adopted for the study as prescribed by Amechi et al. [6], and as such all the samples were first screened for the presence of antibodies to HIV using a highly sensitive rapid test kit-DETERMINE ${ }^{\circledR}$ (Abbott Diagnostic Division, Netherlands) as described by Amechi et al. [6]. The protective foil 
cover of the test pouch was removed and $50 \mu \mathrm{L}$ (i.e. $0.05 \mathrm{ml}$ ) of plasma was applied to the sample-pad. After waiting for the plasma to migrate through the control and test windows, the result was read according to the manufacturer's instruction.

\subsection{EIA (Confirmation)}

All the subjects that tested positive at baseline screening were confirmed to be truly positive using EIA technique, which was able to detect the presence of both antibodies to HIV as well as HIV antigen. This was done using Genscreen ${ }^{\circledR}$ Ultra HIV Ag-Ab manufactured by Bio-Rad, France and as described by Tagny [7].

\subsection{CD4 count}

The CD4 population of positive subjects was assayed using Cyflow Counter manufactured by Partec Germany [8].

$20 \mu \mathrm{L}$ of CD4+ antibody was dispensed into Rhoren tube. $20 \mu \mathrm{L}$ of well-mixed EDTA anti-coagulated blood was added and mixed, the mixture then was incubated for 15 minutes in the dark and then mixture was brought out of the incubator and mixed again. $80 \mu \mathrm{L}$ of CD4 buffer (supplied by the manufacturer) was added and mixed, this was then loaded into the PartecCyflow Counter II for assaying. The CD4+ count was thereafter automatically calculated and printed out by PartecCyflow Counter II.

\subsection{Pcr/Viral Load}

Samples which tested positive at baseline and which were confirmed to so by EIA technique were finally confirmed to be truly positive through polymerase chain reaction, which also assayed the viral load of each positive sample. The molecular study was carried out using COBASAmplprep/Taqman by Roche Diagnostic, USA, as described by Maritz et al. [9].

\subsection{Statistical Analysis}

Data generated in the study were analysed with Microsoft Excel and SPSS.

\section{Result}

The subjects comprised of 421 (42.1\%) males and 571 (57.1\%) females, 8 (0.8\%) didn't disclose their gender (Table 1 and Figure 1). Also, 407 (40.7\%) fell within the $\leq 20$ age-bracket, 521 (52.1\%) were within 21-30 age-bracket, 22 (2.2\%), 12 (1.2\%) were in 31 - 40 and $\geq 41$ brackets respectively, 38 (3.8\%) didn't disclose their age-brackets (Table 2 and Figure 2). Nine hundred and nineteen (91.9\%) of the subjects were single, while 54 (5.4\%) were married. Those who didn't disclose their marital status were 27 (2.7\%) (Table 3 and Figure 3) The study reveals that $4(0.4 \%)$ out of the 1000 subjects were HIV positive, thus representing a $0.4 \%$ seroprevalence.

All the subjects who had antibodies to HIV in their blood were from just two out of the ten selected tertiary schools (Figure 4). The positive subjects had CD4 
counts (Table 4) of 479/L, 368/L, 420/L and 1063/L (mean, 582.5 and SD, 323.5). Two of the subjects had lower-than-detectable levels of viral load (Table 4),

Table 1. Distribution of subjects by gender.

\begin{tabular}{cccc}
\hline SCHOOL & Male & Female & Undisclosed \\
\hline EKSU & 32 & 67 & 1 \\
AAUA & 60 & 40 & 0 \\
AUO & 47 & 50 & 3 \\
FUTA & 75 & 25 & 0 \\
COEI & 35 & 65 & 0 \\
COHI & 29 & 70 & 1 \\
FABOTAS & 21 & 78 & 1 \\
FUOYE & 56 & 44 & 0 \\
FPA & 41 & 58 & 1 \\
CP & 25 & 74 & 1 \\
Total & 421 & 571 & 8 \\
\hline
\end{tabular}

Table 2. Subjects' age-distribution.

\begin{tabular}{cccccc}
\hline SCHOOL & $\leq 20$ & $21-30$ & $31-40$ & $\geq 41$ & Undisclosed \\
\hline EKSU & 44 & 48 & 0 & 0 & 8 \\
AAUA & 25 & 75 & 0 & 0 & 0 \\
AUO & 50 & 46 & 4 & 0 & 0 \\
FUTA & 49 & 48 & 1 & 0 & 2 \\
COEI & 37 & 57 & 0 & 0 & 6 \\
COHI & 28 & 65 & 1 & 3 & 3 \\
FABOTAS & 35 & 32 & 16 & 8 & 3 \\
FUOYE & 81 & 15 & 0 & 1 & 6 \\
FPA & 22 & 72 & 0 & 0 & 1 \\
CP & 36 & 63 & 0 & 0 & 38 \\
total & 407 & 521 & 22 & 12 & 3 \\
\hline
\end{tabular}

Table 3. Marital status.

\begin{tabular}{cccccc}
\hline & Single & Married & Divorced & Undisclosed & Others \\
\hline EKSU & 95 & 3 & 0 & 2 & 0 \\
AAUA & 92 & 2 & 0 & 6 & 0 \\
AUO & 90 & 8 & 0 & 2 & 0 \\
FUTA & 97 & 0 & 0 & 3 & 0 \\
COEI & 95 & 2 & 0 & 3 & 0 \\
COHI & 95 & 4 & 0 & 1 & 0 \\
FABOTAS & 67 & 26 & 0 & 7 & 0 \\
FUOYE & 100 & 0 & 0 & 0 & 0 \\
FPA & 92 & 6 & 0 & 2 & 0 \\
CP & 96 & 3 & 0 & 1 & 0 \\
Total & 919 & 54 & 0 & 27 & 0 \\
\hline
\end{tabular}


Table 4. Positive subjects' CD4 count/viral load.

\begin{tabular}{ccccccc}
\hline Positive Subjects' Code & School & Gender & Age-Bracket & Marital Status/Level & CD4 Count & PCR (Viral Load) \\
\hline SBJ 1 & COHI & Male & $\leq 20$ & Single $/ 100 \mathrm{~L}$ & $479 / \mathrm{L}$ & $325 \mathrm{cp} / \mathrm{ml}$ \\
SBJ 2 & FABOTAS & Female & $21-30$ & Single $/ 100 \mathrm{~L}$ & $368 / \mathrm{L}$ & $<20 \mathrm{cp} / \mathrm{ml}$ \\
SBJ 3 & FABOTAS & Female & $31-40$ & Married $/ 200 \mathrm{~L}$ & $420 / \mathrm{L}$ & ND \\
SBJ 4 & FABOTAS & Female & $\leq 20$ & Single $/ 100 \mathrm{~L}$ & $1063 / \mathrm{L}$ & ND \\
\hline
\end{tabular}

COHI: College of Health Sciences and Technology, Ijero-Ekiti; FABOTAS: Fabotas College of Health Sciences and Technology, Ado-Ekiti; ND: Copies present too few to be detected.

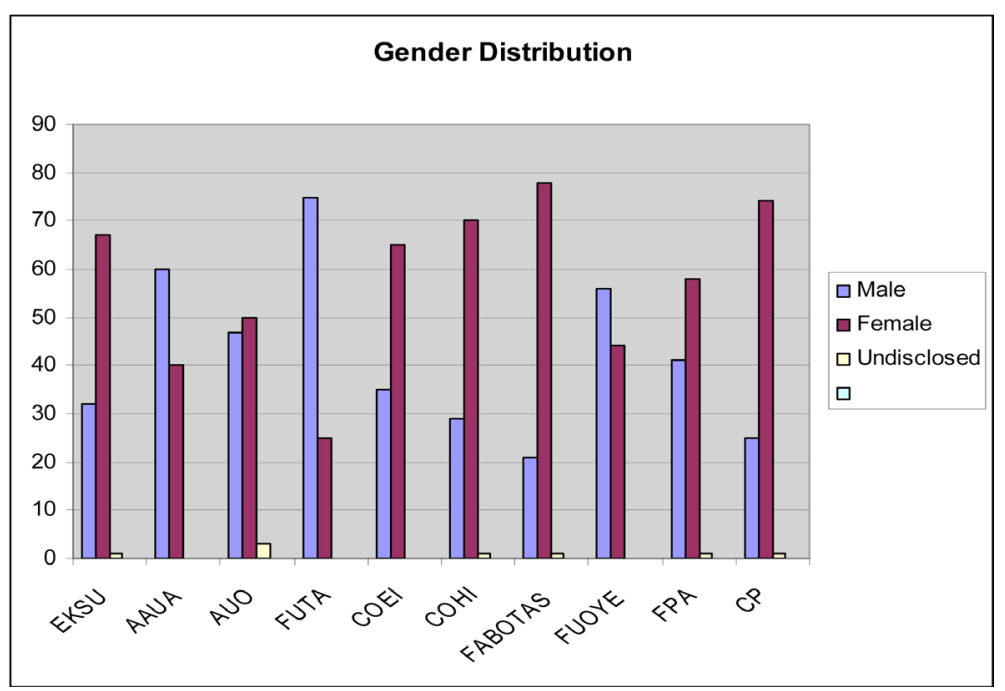

EKSU: Ekiti State University, Ado-Ekiti; AAUA: Adekunle Ajasin University, Akungba-Akoko; AUO: Achiever's University, Owo; FUTA: Federal University of Technology, Akure; COEI: College of Education, Ikere-Ekiti; COHI: College of Health Sciences and Technology, Ijero-Ekiti; FABOTAS: Fabotas College of Health Technology, Ado-Ekiti; FUOYE: Federal University, Oye-Ekiti; FPA: Federal Polytechnic, Ado-Ekiti; CP: Crown Polytechnic, Ado-Ekit.

Figure 1. Subjects' Gender Distribution.

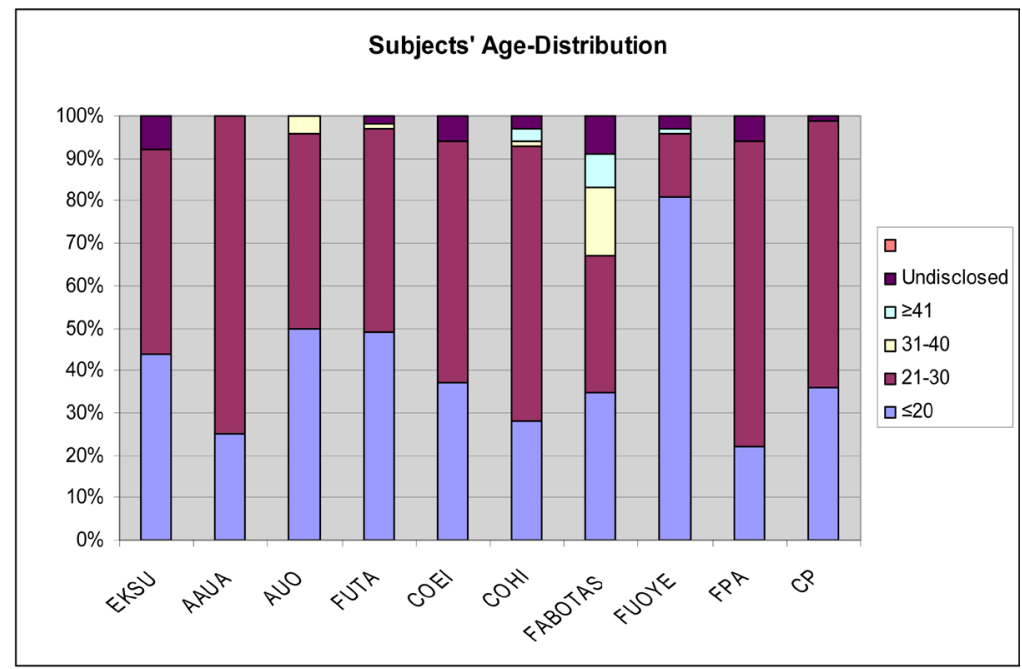

EKSU: Ekiti State University, Ado-Ekiti; AAUA: Adekunle Ajasin University, Akungba-Akoko; AUO: Achiever's University, Owo; FUTA: Federal University of Technology, Akure; COEI: College of Education, Ikere-Ekiti; COHI: College of Health Sciences and Technology, Ijero-Ekiti; FABOTAS: Fabotas College of Health Technology, Ado-Ekiti; FUOYE: Federal University, Oye-Ekiti; FPA: Federal Polytechnic, Ado-Ekiti; CP: Crown Polytechnic, Ado-Ekit.

Figure 2. Subjects' Age Distribution. 


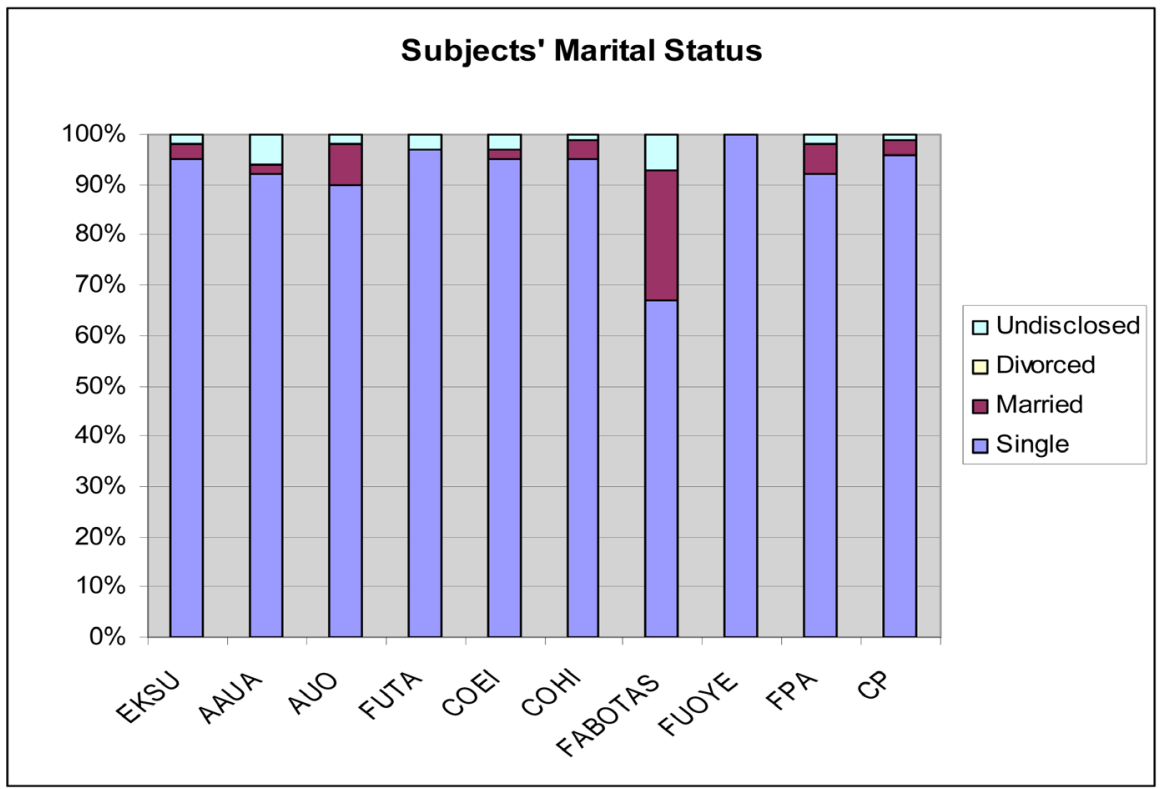

EKSU: Ekiti State University, Ado-Ekiti; AAUA: Adekunle Ajasin University, Akungba-Akoko; AUO: Achiever's University, Owo; FUTA: Federal University of Technology, Akure; COEI: College of Education, Ikere-Ekiti; COHI: College of Health Sciences and Technology, Ijero-Ekiti; FABOTAS: Fabotas College of Health Technology, Ado-Ekiti; FUOYE: Federal University, Oye-Ekiti; FPA: Federal Polytechnic, Ado-Ekiti; CP: Crown Polytechnic, Ado-Ekiti.

Figure 3. Distribution of subjects' marital status.

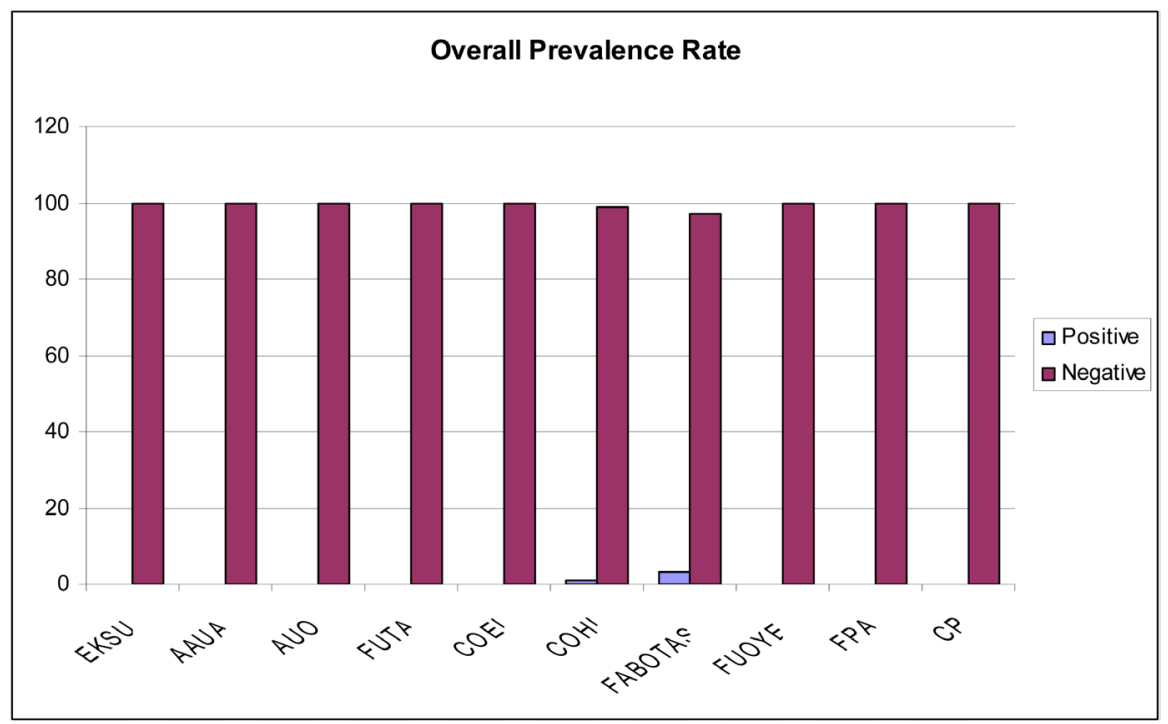

EKSU: Ekiti State University, Ado-Ekiti; AAUA: Adekunle Ajasin University, Akungba-Akoko; AUO: Achiever's University, Owo; FUTA: Federal University of Technology, Akure; COEI: College of Education, Ikere-Ekiti; COHI: College of Health Sciences and Technology, Ijero-Ekiti; FABOTAS: Fabotas College of Health Technology, Ado-Ekiti; FUOYE: Federal University, Oye-Ekiti; FPA: Federal Polytechnic, Ado-Ekiti; CP: Crown Polytechnic, Ado-Ekiti.

Figure 4. Overall Prevalence.

while the remaining two had viral loads of $325 \mathrm{cp} / \mathrm{ml}$ and $<20 \mathrm{cp} / \mathrm{ml}$ (mean, $172.5, \mathrm{SD}, 215.5)$.

Of the 4 positive subjects, 1 (25\%) was single, while $3(75 \%)$ were married 
(Figure 5); 1 (25\%) was a male, while 3 (75\%) were females (Figure 6). Two (50\%) out of the four positive subjects fell within the $\leq 20$ age-bracket, one each fell within the 21 - 30 and 31 - 40 (Figure 7). Suspected blood-related predisposing factors were found to be insignificant in the study in the rate at which HIV was transmitted among the study populace in general or among the positive subjects. None of positive subjects had a history of blood transfusion, surgery, needle-sharing or skin-tattooing (Figure 8). Two (50\%) of the positive subjects had just one sex-partner, while the remaining two had indicated that they had 0 (50\%) sex-partners (Figure 9). This of course sounded very curious and incredible particularly given the fact that none of them ever had surgery, blood transfusion or had any risky encounter with blood or blood products. This was therefore interpreted to mean that these two positive subjects who indicated that they had no sex-partner, either meant that as at the time of the study they had no active sex-partners or they were not being truthful. Analysis of the level of (in) fidelity of the positive subjects reveals that one of them was faithful to his/her sex-partner without being sure of the partner's fidelity, one was mutually faithful to partner, one indicated that (in) fidelity was not applicable to him/her (for whatever reasons), while the remaining positive subject didn't disclose level (in) fidelity between self and sex-partner (Figure 10). At sexual debut, 2 (50\%) of the positive subject were within the 16 - 20 age-bracket, while the remaining 2 (50\%) were within the 21 - 30 age-bracket (Figure 11). Also, none of the 4 positive subjects had a history of sexually transmitted disease (Figure 12).

\section{Discussion}

Though the finding of this study would appear to be heart-warming and pleasing to health policy-makers in general and those in the fore-front of the battle against the spread of HIV/AIDS in particular, however, it'll be wise to sustain the high tempo of anti-HIV campaigns that had led to the lowering of prevalence rates nation-wide. The low prevalence among the high-risk group as discovered by this study can be rightly attributed to some favourable factors. First, the over-

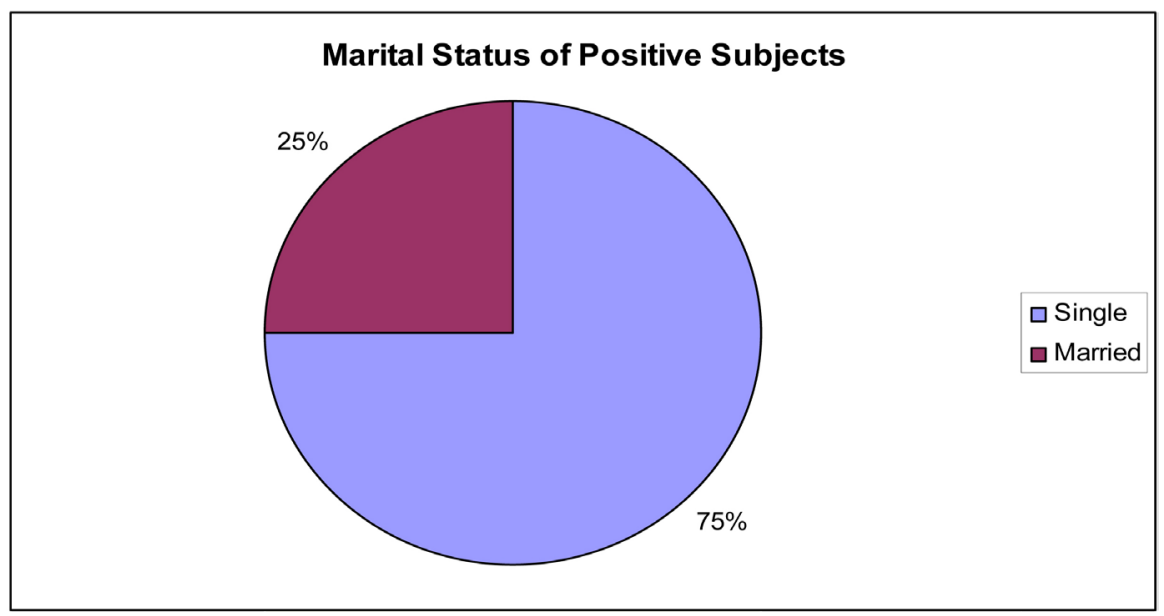

Figure 5. Positive subjects' marital status and gender distribution. 


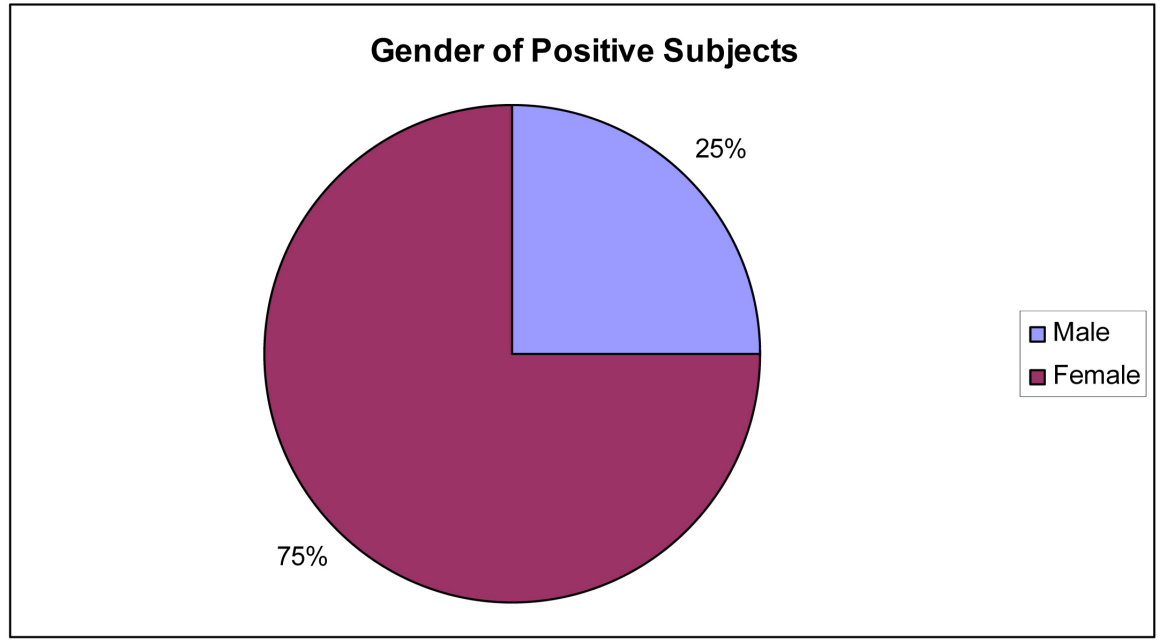

Figure 6. Positive subjects' marital status and gender distribution.

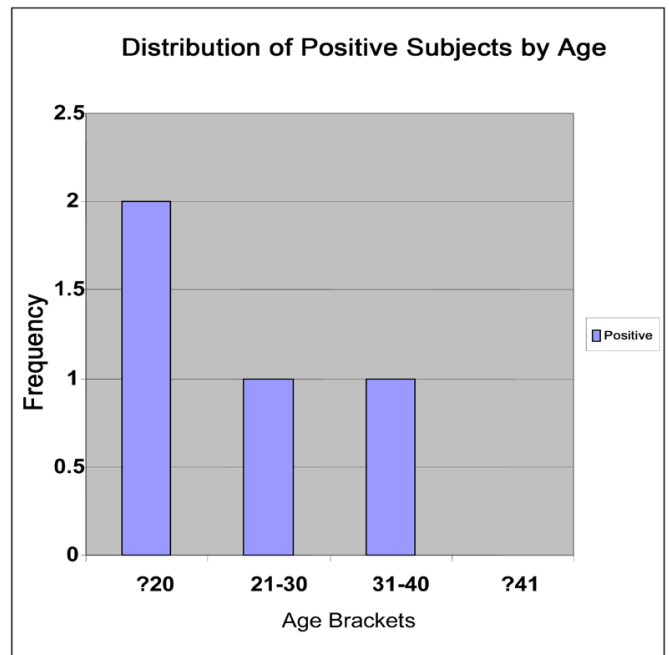

Figure 7. Positive subjects' age-distribution.

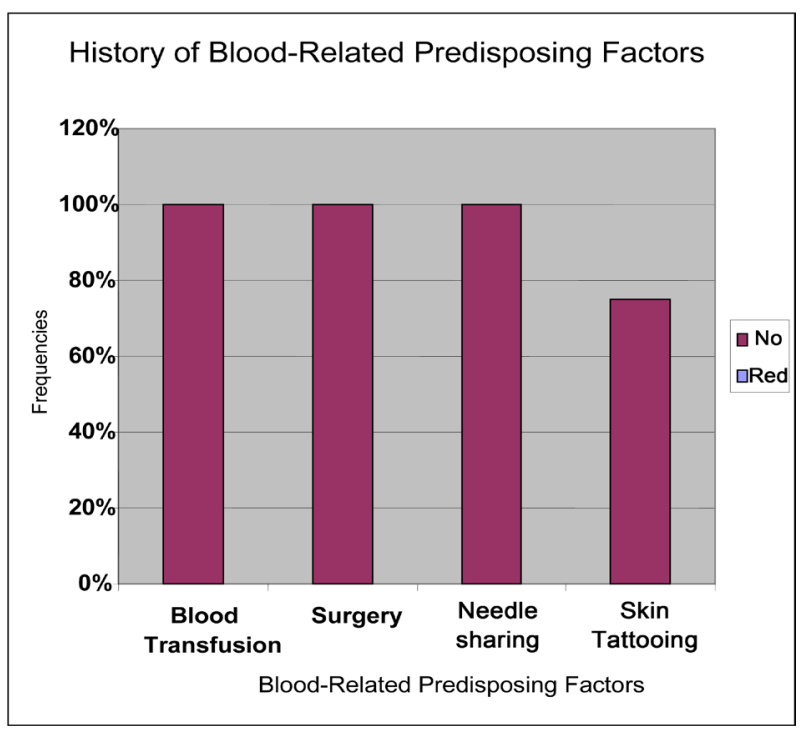

Figure 8. Blood-related predisposing factors. 


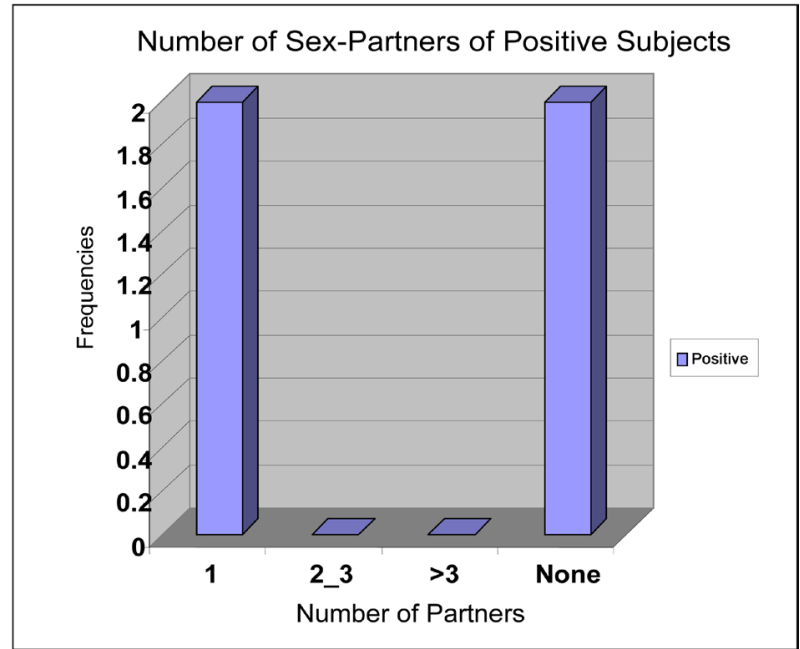

Figure 9. Number of sex-partners of positive subjects.

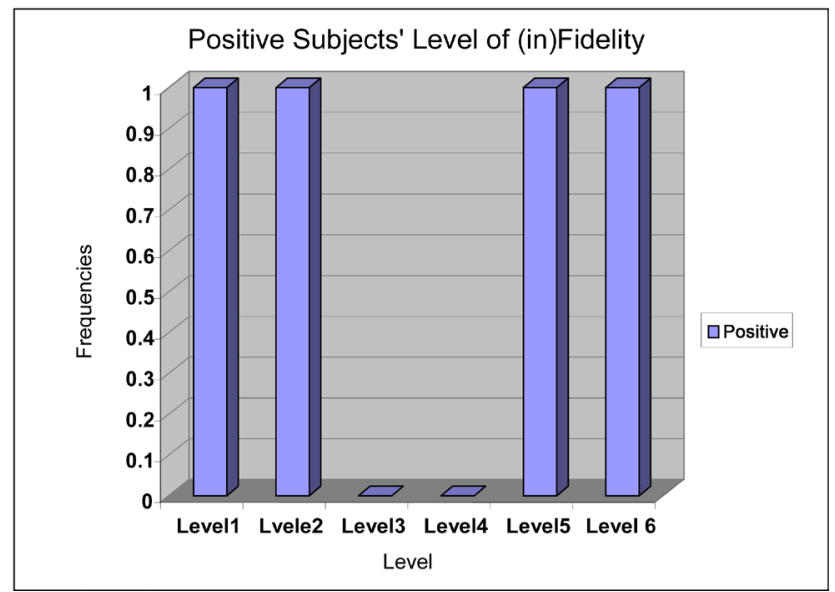

Level 1: Subject was faithful but wasn't sure if partner was; Level 2: Mutually Faithful; Level 3: Partner was Faithful but subject; wasn't; Level 4: Mutual Infidelity; Level 5: Not Applicable; Level 6: Undisclosed/Invalid.

Figure 10. Level of (in)fidelity of the positive subjects.

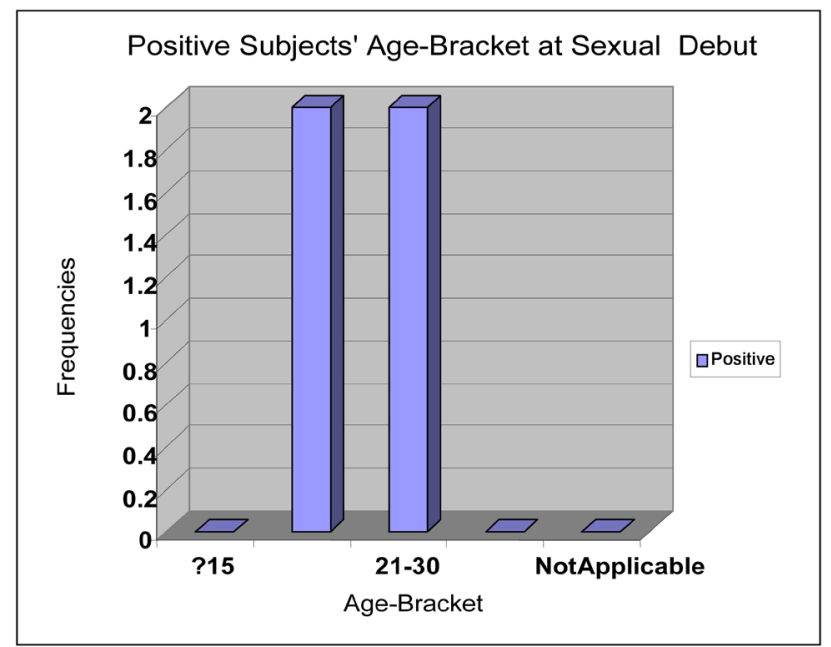

Figure 11. Age at sexual debut. 


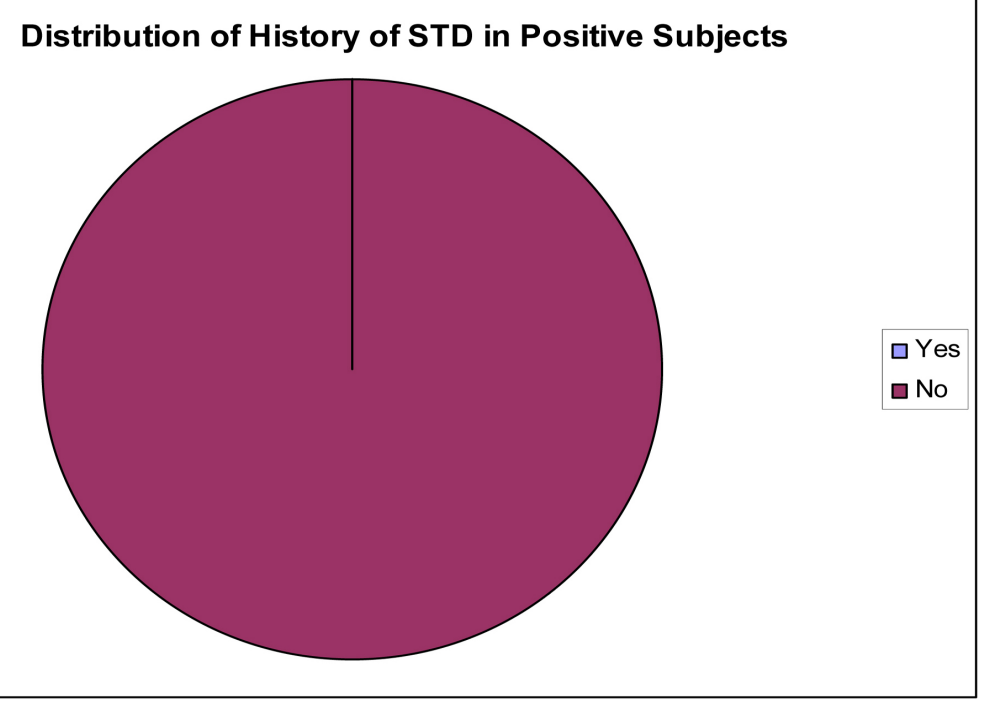

Figure 12. History of STD among positive subjects.

all HIV sero-prevalence among the general populace in Ekiti and Ondo States, is low. In fact, Ekiti State presently has the lowest prevalence (1.0\%) among all the 36 states of the federation and the FCT (Federal Capital Territory). It is only logical to expect that the States' overall prevalence will greatly affect this sectoral prevalence.

Two, the increased level of awareness of HIV/AIDS among the general populace and particularly among the youths [10] has in no small measure contributed to the low prevalence. This high level of awareness and knowledge about HIV was one of the cardinal findings of Otokpa et al. [11] in their recent study a little above a year ago in Abuja. Otokpa, Lawoyin and Asuzu of the Department of Community Medicine at the University of Abuja Teaching Hospital, Gwagwalada, Abuja, administered semi-structured questionnaires on 420 gravid women attending five different antenatal clinics in Gwagwalada. At the end of the survey they discovered that as high as $92.8 \%$ of the respondents were aware about the existence and reality of HIV/AIDS. Also, approximately $60 \%$ of the subjects knew that AIDS has no known cure, while 33\% were aware that an HIV positive person may actually look and feel healthy. Harding et al. [12] in their survey which involved 380 students of a Nigerian university drawn from five different faculties of the university, and reported a high level of awareness about HIV/AIDS among the undergraduates. In the study, they administered questionnaires on respondents and sought information from the students concerning their knowledge about transmission, symptoms and prevention of HIV/AIDS. Also, they included questions about the subjects' sex-life, past and present. The outcome of the study revealed that majority of the subjects were aware about the reality and existence of HIV/AIDS. Awareness and knowledge about HIV/AIDS has been rising, even from the early years of HIV/AIDS in Nigeria, when the pandemic was just taking root in the country. In August-October, 1991, Gugnani and Ukeje [13] conducted an HIV awareness survey among undergraduates of a 
Nigerian university. They served structured questionnaires on 236 undergraduates with a view to determine their level of awareness and attitude about HIV/AIDS and the consequent impact of such awareness on their sexual behaviour. They discovered that nearly all the medical students among the respondents were aware about HIV/AIDS' existence. Equally, they found that only 3.8\% of the non-medical students believed that HIV/AIDS was yet to get to Nigeria, thus implying that even among the non-medical undergraduates, the level of awareness was very high. They therefore concluded that the level of knowledge about the modes of transmission of HIV/AIDS among the study population was adequate.

This is further reinforced by the fact that 341 (34.1\%) of the 1000 subjects knew their HIV status. And this is a total departure from the reality on ground 10 or 20 years ago. Quite desirably, the level of HIV awareness is rising by the day and this has been corroborated by various workers. Three, increase in the use of condom by the sexually active members of the society and especially those who engage in indiscriminate and risky sexual behaviour. The youths no doubts are known to engage in risky behaviours like, having multiple sex partners, needle-sharing, skin-tattooing etc., but as a result of sustained intense anti-HIV campaigns, the youths just like members the larger society have started realising the wisdom in the use of condom. A retrospective study carried out about a year ago found that a clear majority of the youths had used condoms at least once before [14]. The researchers in their retrospective study gathered data from about 1575 single male youths aged 15 - 24 from the National Demographic and Health Survey. The mean age of the unmarried male youth was $20.5 \pm 2.4$. They analysed their collected data using chi-square and logistic regression (alpha = $5.0 \%)$. At the end of the statistical analyses of the datasets, they discovered that $62 \%$ of the respondents had used condom before and that approximately $50 \%$ were currently using condom as the time of the survey.

Four, the falling national prevalence has also been helping matters is no small measure. For quite some years now, the national HIV prevalence level has gratefully been falling.

However, certain unmistakably and probably disturbing patterns can be observed from the findings of the study.

Distribution of HIV among the schools, revealed a rather surprising pattern. No positive case was recorded in any of the 5 universities, 2 polytechnics and the only college of education, rather all the positive cases were recorded in the two monotechnics.

This is one of the striking features of the findings of this study. All the positive subjects were students of Colleges of Health Technology, meaning that all other categories of schools included in the study recorded zero percent HIV prevalence, while $100 \%$ of all the positive cases were found in the two monotechnices. A similar difference has also been reported by researchers who carried out HIV prevalence studies among students of the Polytechnic and the University of Namibia (UNAM). A higher prevalence rate $(2.8 \%)$ was found at the polytechnic 
compared to the prevalence among the undergraduates of UNAM. The workers attributed the difference in the prevalence rate among UNAM and The Polytechnic undergraduates to the different social-demographic areas and background from which the students were drawn [15]. A further close look at even the monotechnics were positive cases were recorded-shows that $3(75 \%)$ of the positive cases were found in the private monotechnics while 1 (25\%) was found in the public monotechnic.

While this of course cannot be interpreted to mean that the university undergraduates who posted zero prevalence were less sexually active than students of the monotechnics or that the undergraduates of the polytechnics and the College of Education were saintlier or more sanctimonious than the undergraduate of these two monotechnices. However, the roles of some factors in the uneven distribution of the positive cases among the four different categories of investigated schools cannot be discounted or belittled. Notable among these factors, is marital status. The Colleges of Health Technology have disproportionately higher number of both legally married couples and unmarried but co-habiting singles. About $56 \%$ of the married subjects in the entire study populations were students of the Colleges of Health Technology and quite interestingly approximately nearly half ( $48.1 \%$ i.e. 26 out of 54 ) of the total number of married students in the study population were found in the private monotechnic.

\section{Conclusion}

With an overall prevalence rate of $0.4 \%$ as depicted by Figure 4 among an otherwise high-risk group that engages in risky sexual behaviour, one can say the efforts and activities of the various SACAs (States Agencies for the Control of AIDS), LACAs (Local Agencies for the Control of AIDS), CACAs (Churches Agencies for the Control of AIDS) and NACA (National Agency for the Control of AIDS) are already yielding positive results. However, there's the need to sustain and even possibly step-up ongoing advocacy campaigns to stem the tide of HIV/AIDS. Also, it is necessary to particularly direct group-focused campaign activities at the womenfolk to sensitise them about the need to exercise higher and greater caution than the men, since studies upon studies have proven that women are much more vulnerable to HIV infection than their male counterparts.

\section{References}

[1] Gallo, Salahunddin, S. and Popovic, M. (1984) Frequent Detection and Isolation of Cytopathic Retroviruses HTLV-III from Patients with AIDS. Science, 224, 497-500. https://doi.org/10.1126/science.6200936

[2] Kanki, P.J. and Adeyi, O. (2006) AIDS in Nigeria: A Nation on a Threshold. APIN, Ibadan.

[3] UNDP (2004) Human Development Report. United Nations Development Program, New York, 141.

[4] National Agency for the Control of AIDS (2007) Nigeria UNGASS Report. National 
Agency for the Control of AIDS, Abuja.

[5] UNAIDS (2008) Epidemiological Fact Sheets on HIV/AIDS and Sexually Transmitted Infections: Nigeria. http://www.who.int/hiv/pub/epidemiology/pubfacts/en

[6] Amechi, B.O., Osagie, R.N. and Chikwendu, C.I. (2012) Evaluation of False Positivity and Cross Reactivity in the Investigation of Human Immunodeficiency Virus Antibodies. International Journal of Community Research, 1, 54-59.

[7] Tagny, C.T., Mbanya, D., Murphy, E., Lefrere, J.J. and Laperche, S. (2011) Reduction of the Risk of Transfusion-Transmitted HIV Infection by Using an HIV Antigen-Antibodies Combination Assay in Blood Donation Screening in Cameroon. Transfusion, 51, 184-190. https://doi.org/10.1111/j.1537-2995.2010.02782.x

[8] Pattanapanyasat, K., Lerdwana, S. and Noustri, E. (2005) Evaluation of a New Single-Parameter Volumetric Flow Cytometer (Cyflow) for the Enumeration of Absolute CD4 T Lymphocytes in HIV Type 1 Infected Thai Patients. Clinical Diagnosis and Laboratory Immunology, 12, 1416-1424.

[9] Maritz, J., Preisser, W. and van Zyl, G.U. (2012) Establishing Diagnostic Cut-Off Criteria for the COBAS AmpliPrep/COBAS TaqMan HIV-1 Qualitative Test through Validation against the Amplicor DNA Test v1.5 for Infant Diagnosis Using Dried Blood Spots. Journal of Clinical Virology, 53, 106-109.

https://doi.org/10.1016/j.jcv.2011.12.002

[10] Unadike, B.C., Ekrikpo, U.E. and Bassey, E.A. (2012) Awareness, Knowledge and Perception of HIV/AIDS and Sexual Behaviour amongst Pre-Clinical, Medical Students in a NIGERIAN University. Nigerian Journal of Medicine, 21, 272-276.

[11] Otokpa, A.O., Lawoyin, T.O. and Asuzu, M.C. (2013) HIV/AIDS-Related Knowledge and Misconception among Women Attending Government-Owned Antenatal Clinics in Gwagwalada Area Council of Abuja, Nigeria. Africa Journal of Reproductive Health, 17, 114-121.

[12] Harding, A.K., Anadu, E.C., Gray, L.A. and Champeau, D.A. (1999) Nigerian University Students' Knowledge, Perceptions and Behaviour about HIV/AIDS: Are These Students at Risks? Journal of R SocPromot Health, 119, 23-31. https://doi.org/10.1177/146642409911900105

[13] Gugnani, A. and Ukeje, M.A. (1993) A Study on Existing Knowledge about AIDS among Undergraduates of a Nigerian University. Journal of Communicable Diseases, 25, 52-56.

[14] Adebowale, A.S., Titiloye, M., Fagbamigbe, A.F. and Odunayo, J.A. (2013) Statistical Modelling of Social Risk Factors for Sexually Transmitted Diseases among Youths in Nigeria. African Journal of Reproductive Health, No. 17, 3. https://doi.org/10.3855/jidc.2272

[15] Jade, M. (2012) HIV Prevalence among Tertiary Students: Startling Figures. http://www.informante.web.na/ 
Submit or recommend next manuscript to SCIRP and we will provide best service for you:

Accepting pre-submission inquiries through Email, Facebook, LinkedIn, Twitter, etc. A wide selection of journals (inclusive of 9 subjects, more than 200 journals)

Providing 24-hour high-quality service

User-friendly online submission system

Fair and swift peer-review system

Efficient typesetting and proofreading procedure

Display of the result of downloads and visits, as well as the number of cited articles Maximum dissemination of your research work

Submit your manuscript at: http://papersubmission.scirp.org/

Or contact jbm@scirp.org 